\title{
Travellers' Diarrhoea: A Military Problem?
}

\author{
Maj P Connor \\ MB,MRCPI.RAMC * **

\section{Professor MJG Farthing $B S C, M D, F R C P^{*}$}

* Digestive Diseases Research Centre, St Bartholomew's \& The Royal London School of Medicine and Dentistry, Turner Street, London E1 $2 A D$

* Royal Defence Medical College, Fort Blockhouse, Gosport, Hants POI2 $2 A B$

SUMMARY: One hundred years ago, apart from the treatment of war injuries, the prevention and treatment of diarrhoea was the dominant preoccupation of the deployed military doctor. Since then our understanding of the pathogenesis and pathophysiology of enteric disease has developed exponentially and our armamentarium for the treatment of enteric diseases has expanded considerably. However, diarrhoea continues to be the dominant military medical concern in deployed units. Here, we examine the evidence for this, discuss the reasons why and critically evaluate current modes of prevention and treatment that are now available to the military medical officer.

\section{Introduction}

Travellers' diarrhoea (TD) is most commonly defined as the passage of three or more loose stool motions within 24 hours in a person travelling from a developed country to an underdeveloped country. Other definitions can be used (1), but all consist of a combination of change in stool consistency and associated symptoms such as nausea, vomiting, abdominal pain or cramps, urgency to defecate, blood in the stools and fever, as well as loss of appetite and general malaise. It is the most common medical condition affecting travellers to countries regarded as high risk (Table 1). It is usually a self limiting illness lasting on average 3 - 5 days. However, it can produce symptoms for more than 1 month in $2 \%$ and more than 2 months in $1 \%$, of those affected (2). Despite advances in the understanding of the causes of TD and the knowledge regarding reservoirs and modes of transmission of TD pathogens, advice given to travellers has little impact in reducing the attack rate (3). Estimated current prevalence (1997-8) of TD in British travellers to areas such as Egypt, Kenya, Dominican Republic and Mexico remains in the order of $65-70 \%$ (Personal communication, Professor RY Cartwright, Consultant microbiologist, Microdiagnostics UK, Ltd).

Table 1

Geographical risk of contracting travellers' diarrhoea.

\begin{tabular}{|l|l|l|}
\hline High Risk & Intermediate Risk & Low Risk \\
\hline Central America & Mediterranean Basin & North America \\
South America & Caribbean (Parts) & Northern Europe \\
(except Chile) & Chile & Eastern Europe (Parts) \\
Caribbean (Parts) & South Africa & Australia \\
Africa (except S Africa) & Eastern Europe (Parts) & New Zealand \\
Indian Subcontinent & & \\
Middle East & & \\
South East Asia & & \\
\hline
\end{tabular}

Diarrhoea has been a major military medical concern in every overseas campaign since records began, with the exception of the Falklands Campaign. After the Crimean war, the Secretary of State for War initiated formal reporting of the state of health and sanitary conditions of the British Army, the first of which was published in 1859 (4). Prior to this it was mainly the writing of independent observers as well as high profile public figures and volunteers such as Florence Nightingale, that documented the disease and conditions affecting troops abroad, thus raising public awareness. Disease and sanitary conditions in the UK were also quite poor at this time and epidemics of diarrhoea were by no means rare occurrences in military establishments, but overall conditions were markedly better than those encountered on the battlefield or by troops stationed in countries such as India, Ceylon and South Africa (4-6).

During and after each major conflict since this time, there have been accounts confirming to the extent, severity and devastating effect of diarrhoea on military units. Inspector-General Muir, reporting on the war in China, 1860 (7), refers to diarrhoea and dysentery being the prevailing afflictions of the British troops. A considerable number of men had to be left behind from the advance on Peking due to this affliction. The report of the Royal Commission on the Boer war in South Africa talks of "the sudden outbreak of an epidemic which is inevitable in war". There are many other accounts testifying to the effect of diarrhoea in this campaign. During and following the first and second world wars there are many accounts of diarrhoea, both endemic and epidemic. It is of no surprise that the highest morbidity rate for diarrhoeal diseases during these wars, was in Africa, the Eastern Mediterranean and further east. However, even in the second world war diarrhoea was a predominant concern in the European theatre and world-wide the American Army lost over one million man days due to amoebiasis alone (8).

During the Korean war, the American forces lost 78,970 days from duty as a result of diarrhoea and dysentery (9). This was paralleled in the crisis in Lebanon in 1958 when diarrhoea led to admission rates of $50 \%$ of ground troops per week, in the first month or so of deployment (10). Diarrhoeal diseases in Vietnam were widespread, and the admission rate to hospital or quarters outstripped malaria by a factor of almost $4: 1$, making it the largest single disease entity in the war (10).

Diarrhoea was a major medical concern during the Gulf War in 1991(Weekly Health and Hygiene Report, Medical Branch, HQ FMA (Gulf), 4 December 1991). Throughout the conflict, upwards of $97 \%$ percent of American troops suffered significant diarrhoea (11), and at one time it was estimated that $20 \%$ of their troops had diarrhoea sufficient to prevent their deployment or reduce their fighting effectiveness (12). Post Gulf war in Northern Iraq, British soldiers suffered a $69 \%$ attack rate of diarrhoea within the first 5 weeks of deployment (13).

In 1993, two trials were undertaken in Belize investigating the value of treatment and prevention in the management of diarrhoea in British Marines. During these studies, the placebo groups had an attack rate of diarrhoea approaching $36 \%(14,15)$. 
An epidemiological study undertaken around the same time in Belize, the attack rate among servicemen was about $50 \%$ (16). In a study in Kenya in 1996, diarrhoeal prevalence rate approached $20 \%$ but as this relied only on those reporting sick, it is highly likely that this underestimated the true prevalence (Unpublished Post tour report, Maj R Markham, RAMC).

\section{Aetiology}

The significance of the role played by enteric pathogens in the aetiology of TD only became apparent in the late 1950's and 1960 's. The role of pathogens in classic dysentery was well established. Entamoeba spp, Salmonella spp and Shigella spp were all well documented, as were the clinical syndromes they produced. The failure to culture any known pathogens, along with the usually uncomplicated and short lived clinical course, led to the widely held belief that the cause of non-dysenteric diarrhoea in travellers was as much due to changes in climate, the long and often arduous journeys involved in such travel and "chemicals in the water", as it was to any potentially infective agent $(5,7)$. It was the realisation that Escherichia coli, until then considered a non pathogenic commensal of the gastrointestinal tract, was connected with outbreaks of neonatal diarrhoea (17); further human studies confirmed the possibility of enteric infection from E.coli $(18,19)$ and subsequent work showing the enterotoxigenic nature of some E.coli in pigs and rabbits (20-24), that concentrated research into the infective nature of TD. These early studies, however, were not the first time E.coli had been associated microbiologically with outbreaks of diarrhoea (25). It was however, the first time that E.coli was implicated as a possible causative pathogen. Some of the early microbiological studies were carried out in servicemen (26) and were important landmarks in identifying what is now known to be the pathogen responsible for between 40 and $60 \%$ of cases of TD, enterotoxigenic E.coli (12,27-32). We know also, that despite the remarkable similarity in identifiable causative pathogens from different regions of the world, there are distinct regional differences (29) (Table 2). This, together with regional antibiotic resistance patterns (33-38), impacts not only on treatment but on the wider issue of data acquisition.

It is estimated that $90-95 \%$ of cases of TD can be attributed to an infective agent susceptible to currently available antibiotics (Table2) $(14,39-44)$.

Table 2

Frequency of isolation of specific microbes in high risk areas of the world.

\begin{tabular}{|l|l|l|l|}
\hline Organism & $\begin{array}{l}\text { Latin } \\
\text { America(\%) }\end{array}$ & Asia (\%) & Africa(\%) \\
\hline Enterotoxigenic $E$. coli* & $40-70$ & $20-34$ & 36 \\
Enteroadherent $E$. coli & $?-12$ & $?$ & $?-33$ \\
Enteroinvasive $E$. coli & 6 & 3 & 2 \\
Shigella species & $2-30$ & $2-13$ & $2-15$ \\
Salmonella species & $0-16$ & $11-15$ & $0-4$ \\
Campylobacter jejuni & $1-7$ & $2-15$ & $1-28$ \\
Aeromonas hydrophilia & 2 & $1-57$ & $1-8$ \\
Vibrio cholerae non 01 & $1-4$ & $1-16$ & $0-4$ \\
Rotavirus & $4-36$ & $1-8$ & $0-6$ \\
Entamoeba histolytica & $0-9$ & $2-6$ & $0-2$ \\
Giardia lamblia & $0-9$ & $0-6$ & 0 \\
Microsporidia/Cyclosporal & $?$ & $?$ & $?$ \\
Isospora & $20-30$ & $33-53$ & $15-53$ \\
Undiagnosed & 20 & \\
\hline
\end{tabular}

* Highest rates in rainy summertime

\# Highest rates in dry wintertime.

(From Arduino \& DuPont;Baillieres Clinical Gastroenterology 1993:7(2):

\section{Prevention}

The concept of preventative measures to combat diarrhoeal disease was appreciated more than 100 years ago. The deployment of Sanitary officers with military units is testamen to this. In the Report to the Royal Commission on the war if South Africa, 1903 (6), General Sir Charles Warren commented "From a purely medical point of view, the skill, zeal and devotion to duty of our medical officers during the war is beyond a praise. From the sanitation point of view there is much to b desired". He continued, "I am convinced that typhoid fever doe not belong of necessity to an Army in the field............... whereve real sanitary precautions are taken typhoid fever is at ona reduced to a minimum. I think that three-fourths or four fifths of our losses from typhoid fever would have been avoided" He suggested that the sanitation of camps be the joint respon sibility of the Royal Army Medical Corps and the Roya Engineers.

Since then it has become clear that the only way to reliabl prevent TD is to put in place appropriate environmenta interventions which ensure high water quality and efficien disposal of sewage. This was clearly shown in Salou, a resor town in the Tarragona region of Spain. In 1986 the attack rate fo British visitors to this resort reached $40 \%$ in the height 0 summer. In the latter part of 1989 a new water supply wa provided for the region and the following year the attack rate fo British tourists decreased to $<10 \%$ (2). For the majority developing countries this is unlikely to be achieved in the nea future because of the enormous cost involved in transforming the public and environmental health to the level required Undoubtedly this is the long term objective for many of these countries as it would have the benefit of attracting more visitor and hence much valued foreign revenue. Conversely, as tourism is the major industry of many of these countries, attracting mor visitors is almost certainly the way in which these improvement can be funded.

Militarily, the development of environmental and public healt in these countries is of paramount concern. The end of the Colc War has changed the focus of politicians regarding the deployments of our forces abroad. It is anticipated that the majo role of British (and for the large part, American) forces oversea in the future will be in the support of United Nations and NAT0 led operations in active, peacekeeping and "hearts \& minds roles. In recent years this policy has seen the British Armed Forces deployed to West Africa, Central/Eastern Africa, The Balkans, South East Asia and the Middle East (amongst others all regarded as high risk, or potentially high risk areas. Whil data emanating from these deployments suggests that diarrhoe diseases were not a significant problem in terms of impacting o unit effectiveness and efficiency, the numbers deployed wer relatively small and the support provided comparatively large The deployment of larger numbers of ground troops to one these areas or prolongation of deployment in this environmen should that be required, would pose a much larger threat a environmental control and personal hygiene break down.

Individuals must, therefore, to some extent control their ow environment and minimise the risk of exposure. TD is usuall associated with the ingestion of contaminated food or water. I areas where contamination is minimal the incidence of enter disease is correspondingly small. Conversely, in areas wher contamination of food and water is high the incidence of enteri infection in travellers can reach as high as $70 \%$. Kozicki et al (3 clearly showed that where little care is taken in the consumptio of food and drink, the rate of diarrhoea is significantly highe than if traditional advice is followed. Two studies in Mexic $(45,46)$ showed that in travellers who ate where food and wate hygiene were controlled, i.e. in private residences, the rate of TL was lower than in travellers who ate the majority of their meal from restaurants, cafeterias and, particularly, from street vendor This paralleled the contamination levels of bacteria found i 
foods in these establishments. The type of food eaten also relates to the risk of developing TD. Kendrick in 1972 (47) and Gangarosa in 1980 (48) showed a relationship between the consumption of raw meat, raw fish, raw vegetables and shellfish, and the prevalence of diarrhoeal disease. Although faecally contaminated food and water (including ice) can be implicated as the cause of the majority of cases of TD, person to person spread is thought to account for some cases. The epidemic nature of Norwalk virus outbreaks strongly suggests person to person transmission and indeed this agent has been identified as the cause of several outbreaks of enteric illness on cruise liners (49). There is little evidence that other pathogens are transmitted in this way.

On deployment in the Gulf, supply of good quality, clean and therefore safe food was maintained, for the most part, amongst British forces. Great attention was paid to the supply of safe drinking water. American forces relied to a greater extent (almost certainly due to their vastly greater numbers of ground troops) on food supplied from the localities in which they were stationed $(11,12)$. The consequence of this was a higher prevalence of diarrhoeal diseases amongst American service personnel.

Advice to travellers' concerning preventative measures should incorporate this evidence. Meticulous attention to food preparation and avoidance of high risk eating places, careful selection of food and avoidance of standard water supplies with reliance only on carbonated bottled water in which the acid $\mathrm{pH}$ generally protects against contamination (although at least one report documents an outbreak associated with $S$. typhimurium infected carbonated water) (50), is the minimum message one should convey. Standard water supplies can be made safer by ensuring that only adequately boiled water is used for cooking and drinking, although this does not guarantee protection. In the field setting, the use of Millbank bags and water purification tablets is essential where the safety of the water supply cannot be guaranteed. However, even in those who are highly motivated, the success of this advice alone in preventing TD is limited. In a group of Swiss travellers, Kozicki et al (3) showed that in those visiting Asia or Africa, only $2 \%$ could adhere to this dietary advice, despite their vacation lasting no more than two weeks. This percentage is likely to be higher in a "highly motivated" military population, but the length of deployment almost certainly will be longer, hence the potential for breakdown of personal standards and therefore environmental control.

\section{Prophylaxis}

TD, for the individual, is preventable. Antibiotic prophylaxis trials have achieved efficacy levels of $95 \%(51,52)$. Almost all antibiotics used in the treatment of TD have been shown to be effective for prophylaxis (51-59). The use of antibiotic therapy for a self-limiting disease has been challenged and is generally not recommended (60).

Non-antibiotic prophylactic measures include daily bismuth subsalicylate which has an efficacy of $60 \%$ (61). However, even the introduction of a tablet form has found little favour due to the unpleasant side effects and the concern regarding bismuth absorption and toxicity (2). Early studies of ETEC diarrhoea in piglets showed that colostrum fed piglets were better protected from diarrhoea than piglets fed artificial milk products $(62,63)$. This led to investigations revealing the protective constituent of colostrum to be maternal immunoglobulin (64-66).

Investigators subsequently raised bovine immunoglobulin against what were thought to be the most common strains of enterotoxigenic E.coli and tested its efficacy in the prophylaxis of TD (67). There was protection against oral challenge with ETEC in those given immunoglobulin compared with controls. However, the impracticality of this form of therapy, the cost and the dosing schedule potentially required meant that this was not a feasible option for TD, although the observation is important as it provides further evidence that breast feeding should be encouraged in developing countries.

Various probiotic organisms have been studied for their protective effect in TD $(15,68-73)$ although their value in TD prophylaxis remains controversial. A newer approach being actively investigated is to provide naturally occurring human probiotic strains with selective nutrition such as oligofructose, in an attempt to select out these particular organisms in the flora of the bowel at the expense of potential enteric pathogens.

Militarily, the ideal would be to send soldiers into the field knowing that they were largely protected against diarrhoea. Effective and safe vaccination is one way in which this would be achievable. As ETEC is the predominant pathogen in TD, it would be reasonable to aim for an ETEC vaccine to provide this protection. However, this has been difficult to achieve due to the many virulence determinants which appear to play a part in the production of a protective immune response. The similarity in the mechanisms of disease causation between ETEC and V. cholerae and experimental evidence, in vitro and in vivo, showing cross reactivity of enterotoxin antibodies in these two infections led to the assessment of the value of a relatively new, oral, killed cholera vaccine in the protection against TD (predominantly ETEC). Two studies showed good levels of protection against pure ETEC infection and mixed infections with other pathogens such as Shigella spp and Salmonella spp $(74,75)$. This was a two or three dose vaccine and the protective efficacy was relatively short lived, limiting its usefulness in a military scenario.

What is undoubtedly required is a "one shot" vaccine which gives long lasting protection with a protective efficacy approaching that generated by natural infection. Whilst great advances have been made in vaccine design, we are as yet still some way from a specific TD vaccine. There is hope that a newer single dose, live recombinant cholera vaccine, CVD $103 \mathrm{HgR}$, may provide an acceptable level of protection against ETEC disease, although recent unpublished work suggests that this may not be realised.

\section{Treatment}

TD for the majority, remains a mild and self-limiting illness which requires no more than careful attention to adequate and safe fluid intake. However, in some individuals it may be wise to interrupt the course of the illness, because of the concomitant illness or drug therapy which may exacerbate the effects of TD, in the business traveller to reduce time lost through illness or in an operational military setting. When symptoms are moderate, severe or systemic, or when dysentery occurs, antimicrobial chemotherapy may be indicated. When TD proves to be a problem in the field then safe effective and speedy treatment is warranted.

The basis of treatment of mild to moderate cases of TD is oral rehydration using a glucose-electrolyte solution. These preparations contain sodium and glucose which through their cotransport mechanism in the small bowel, drive fluid and electrolyte absorption. The first solutions were designed to adequately replace electrolyte losses in secretory diarrhoea and tended to mild hypertonicity (76). Various investigators have attempted to manipulate the formulations in order to improve the absorptive quality by reducing osmolality (77-80) adding fibre $(81,82)$, or guar gum $(83,84)$ or using complex carbohydrates in place of glucose $(85,86)$. In the developed world, paediatricians now favour lower sodium ORS while in the developing world, World Health Organisation ORS (WHO ORS) is still widely used. If commercial preparations are not available, encouraging intake of salty soups or fruit juices combined with complex 
carbohydrate such as rice, potato or bread should suffice in older children and adults (49).

In symptomatic individuals who feel the need to intervene further, antimotility agents such as diphenoxylate or loperamide may well provide symptomatic improvement. Although they reduce the number of unformed stools these agents do not shorten the overall illness (87). They should not be used in children under 2 years of age, in individuals with fever or in those with bloody stools $(49,88)$. Bismuth subsalicylate also reduces the number of unformed stools (89) but is not as effective as loperamide (90), and concern as to its safety still exists (2).

In those requiring more definitive treatment, antibiotic therapy has been shown to be effective in reducing all elements of the disease. Many antibiotics have been shown to be effective in the treatment of TD $(12,14,42,88,91-94)$. The length of treatment has been the subject of many trials $(14,93,95)$. Salam et al (14) showed that a single dose of ciprofloxacin $500 \mathrm{mg}$, taken at the onset of illness significantly reduced the duration of diarrhoea and the severity of symptoms. Unfortunately, resistance has developed to many of the antimicrobials used for this purpose $(12,36,37,96,97)$. Resistance has even now developed towards the newer fluoroquinolone antibiotics in South East Asia and Mexico $(33,36,98)$. Current recommendations, based on sensitivity, side-effects and resistance data suggest that, if required, single dose therapy with ciprofloxacin or other 4fluoroquinolones, at the onset of symptoms should be effective in most locations. If symptoms persist then microbiologically obtained antibiotic sensitivity data should direct further antimicrobial therapy.

In some individuals, symptoms persist on return home. Microbiological investigation is desirable and any treatment directed appropriately. Organisms responsible for most cases of prolonged symptomatology are the enteropathogenic protozoa Giardia intestinalis, Entamoeba histolytica, Microsporidia, Isopora belli, Cyclospora cayetanensis and Cryptosporidium parvum. Other causes such as ascaris and strongyloides should not be forgotten. In some travellers, no microbiological cause can be identified and occasionally empirical therapy with metronidazole or tinidazole for presumed giardiasis and cotrimoxazole for presumed Cyclospora spp or Isospora belli may be indicated (99).

Thus diarrhoea continues to be a significant, current, military medical concern, with the potential to reduce the efficiency and effectiveness of a front line unit. It is, or should be therefore, a significant military command concern.

Strategies for the prevention of diarrhoea need to be extended from the immediate control of the environment, with more emphasis given to the individual. Working in concert, these two approaches should ensure that forces deployed in high risk areas are well protected, and therefore the fighting efficiency of units, maintained. WM Muir, MD, CB, Inspector-General and Principle Medical Officer of the Expeditionary Army, reporting on the 1860 war in China (7) said that the Crimean War dissipated the delusion that the evils suffered by those not directly wounded or killed in action (i.e. suffering disease) during wars, were inexorable. The Crimean campaign he said, proved that the miseries of war may be mitigated, if not altogether prevented and that amongst other things, the factors generating death and favouring disease may be obviated or neutralised.

We have come a long way since then in our understanding of the aetiology and epidemiology of diarrhoea, the preventative role of environmental and public health and in the development of effective prophylactic and treatment modalities. We need now, in light of the dramatic changes that have occurred in the political world in the last 10 years, to reassess our needs and be forward thinking in terms of diarrhoea research and planning. We must learn from history, both distant and current, to ensure that whereever and whenever our forces are deployed, they are adequately protected to ensure their efficiency and effectiveness are optimally maintained. This entails being aware of current, worldwide microbiological threats and microbial resistance patterns, as well as up-to-date on current prophylactic and therapeutic strategies. There are excellent opportunities for epidemiological research into diarrhoeal disease in the military setting. Clinical research into newer, safer and more directed forms of therapy should be encouraged. Collaboration between specialities (gastroenterology, infectious diseases, microbiology and public health) is vital if a co-ordinated strategy is to develop. Funding needs to be identified and collaboration with allied military research institutes as well as commercial concerns encouraged where appropriate.

One hundred years ago, the Royal Army Medical Corps were world leaders in diarrhoeal research. Whilst funding and manpower remain as obstacles, we nevertheless have an ideal opportunity to continue to have an impact on an area not only of military importance, but increasingly, of civilian importance. It might not be "sexy", but travellers' diarrhoea continues to be an important area of military medical concern.

\section{REFERENCES}

1. MacDonald KL, CoHEN ML. Epidemiology of travellers' diarrhoea: current perspectives. Rev Infect Dis 1986; 8 (Suppl 2):S117-21.

2. Cartwright RY. Travellers' diarrhoea. Br Med Bull 1993;49: 348-362.

3. Kozicki M, Steffen R, Schar M. 'Boil it, cook it, peel it or forget it': does this rule prevent travellers' diarrhoea? Int J Epidemiol 1985;14:169-172.

4. Anonymous. Statistical, Sanitary and Medical Report. Army Medical Department, 1859;

5. MASSEY D. The treatment of acute dysentery by large doses of Ipecacuanha, in the Regimental Hospital, 2nd Dragoon Guards, during the year 1859, in Oude. In: Anonymous. Statistical Sanitary and Medical report, 1859. Army Medical Department, 1859;280-289.

6. Anonymous. Report of the Royal Commission on the War in South Africa. J R Army Med Corps 1903;1:401-405.

7. MUIR W. Medical History of the War in the North of China. In: Anonymous. Statistical, Sanitary and Medical report, 1860. Army Medical Department, 1860;375-395.

8. Anonymous. Medical statistics in WWII. Washington DC Office of the Surgeon General, Department of the Army 1975 ;

9. Anonymous. Medical statistics of the United States Army 1953. Washington DC: Office of the Surgeon General, 1955

10. Colonel Ralph F Wells UA. Gastrointestinal Diseases Background and Buildup. In: Anonymous. Interna Medicine in Vietnam. Vol II: General Medicine \& Infectious diseases. Washington DC: United States Army Medical Department. 0;345-354.

11. Kilpatrick ME. Diarrhoeal disease: current concepts and future challenges. Diarrhoeal disease-a military perspective. Trans R Soc Trop Med Hyg 1993;87 (Suppl 3):47-48.

12. Hyams KC, Bourgeois AL, Merrell BR, et al. Diarrheal disease during Operation Desert Shield. $N$ Engl $J$ Med 1991;325:1423-1428.

13. Rudland S, Little M, Kemp P, Miller A, Hodge J. The enemy within: diarrheal rates among British and Australian troops in Iraq. Milit Med 1996;161:728-731

14. Salam I, Katelaris P, Leigh-Smith S, Farthing MJ 
Randomised trial of single-dose ciprofloxacin for travellers' diarrhoea. Lancet 1994;344:1537-1539.

15. Katelaris PH, Salam I, Farthing MJ. Lactobacilli to prevent travellers' diarrhoea? N Engl J Med 1995; 333:1360-1361.

16. CONNOR MP, GREEN AD. Travellers' diarrhoea and use of single-dose ciprofloxacin. Lancet 1995;345:381-382.

17. BRAY J. Journal of pathological bacteriology 1945;57:239247.

18. Neter, Shumway. Proc Soc Exp Biol Med 1950;75:504+

19. Ferguson, JunE. Amer J Hyg 1952;55:155+

20. Smith HW, Halls S. J Pathol Bacteriol 1967;93:499-529.

21. Sмiтн HW, Halls S. J Pathol Bacteriol 1967;93:531-543.

22. SMITH HW, HaLlS S. The transmissible nature of the genetic factor in Escherichia coli that controls haemolysin production. J Gen Microbiol 1967;47:153-161.

23. Smith HW, Halls S. Studies on Escherichia coli enterotoxin. J Pathol Bacteriol 1967;93:531-543.

24. SмIтH HW, HaLls S. Observations by the ligated intestinal segment and oral inoculation methods on Escherichi coli infections in pigs, calves, lambs and rabbits. J Pathol Bacteriol 1967;93:499-529.

25. Horrocks WH. The baccilus coli communis: Considered as an indication of sewage contamination of water supplies. $J$ R Army Med Corps 1903;1:362-376.

26. Rowe B, TAYLOR J, BetTelheim KA. An investigation of travellers' diarrhoea. Lancet 1970;1:1-5.

27. TAYLOR DN, ECHEVERria P, BLASER MJ, et al. Polymicrobial aetiology of travellers' diarrhoea. Lancet 1985;1:381-383.

28. Gracey M, Burke V, Robinson J, Masters PL, Stewart J, Pearman J. Aeromonas spp in travellers' diarrhoea. $\mathrm{Br}$ Med J (Clin Res Ed) 1984;289:658.

29. ARduINo RC, DuPONT HL. Travellers' diarrhoea. Baillieres Clin Gastroenterol 1993;7:365-385.

30. BLACK RE. Epidemiology of travellers' diarrhoea and relative importance of various pathogens. Rev Infect Dis 1990;12(Suppl 1):S73-9.

31. HABERBERGER RL, MikHaIl IA, IsmaIL TF. Enteritis due to multiresistant enteroadherent Escherischia coli. Lancet 1991;337:235-236.

32. Mathewson JJ, Johnson PC, DuPont HL, et al. A newly recognized cause of travellers' diarrhoea: enteroadherent Escherichia coli. J Infect Dis 1985;151:471-475.

33. Anonymous. Antibiotic Resistance. Proceedings of a symposium. Southampton, United Kingdom, 12 July 1996. JMed Microbiol 1997;46:436-470.

34. SaCk RB, Rahman M, Yunus M, Khan EH. Antimicrobial resistance in organisms causing diarrheal disease. Clin Infect Dis 1997;24(Suppl 1):S102-5.

35. Mukhopadhyay AK, Basu I, Bhattacharya SK, BHATTACHARYA MK, NAIR GB. Emergence of fluoroquinolone resistance in strains of Vibrio cholerae isolated from hospitalised patients with acute diarrhoea in Calcutta, India [letter]. Antimicrob Agents Chemother 1998;206-207.

36. Hoge CW, Gambel JM, Srijan A, Pitarangsi C, ECHEVERRIA P. Trends in antibiotic resistance among diarrheal pathogens isolated in Thailand over 15 years. Clin Infect Dis 1998;341-345.

37. RuIz J, Goni P, MARCO F, et al. Increased resistance to quinolones in Campylobacter jejuni: a genetic analysis of gyrA gene mutations in quinolone-resistant clinical isolates. Microbiol Immunol 1998;42:223-226.

38. BARRY AL, FuCHS PC. Antibacterial activities of grepafloxacin, ciprofloxacin, ofloxacin and fleroxacin. $J$
Chemother 1997;9:9-16.

39. Kuschner RA, Trofa AF, Thomas RJ, et al. Use of azithromycin for the treatment of Campylobacter enteritis in travellers to Thailand, an area where ciprofloxacin resistance is prevalent. Clin Infect Dis 1995;21:536-541.

40. Mattila L, Peltola H, Sirtonen A, Kyronseppa H, Simula I, Kataja M. Short-term treatment of travellers' diarrhoea with norfloxacin: a double-blind, placebo-controlled study during two seasons. Clin Infect Dis 1993;17:779-782.

41. StefFen R, Jori R, DuPont HL, Mathewson JJ, STURCHLER D. Efficacy and toxicity of fleroaxcin in the treatment of travellers' diarrhoea. Am J Med 1993;94:182S$186 \mathrm{~S}$.

42. DuPont HL, Ericsson CD, Mathewson JJ, DuPont MW. Five versus three days of ofloxacin therapy for travellers' diarrhoea: a placebo-controlled study. Antimicrob Agents Chemother 1992;36:87-91.

43. Christensen OE, Tuxen KK, Menday P. Treatment of travellers' diarrhoea with pivmecillinam $J$ Antimicrob Chemother 1988;22:570-571.

44. Bouree P, Kouchner G, Ponti M. Double-blind study of travellers' diarrhoea using Nifuroxazide. Trans $R$ Soc Trop Med Hyg 1987;81:859.

45. TJOA WS, DuPONT HL, Sullivan P, et al. Location of food consumption and travellers' diarrhoea. Am J Epidemiol 1977;106:61-66.

46. Ericsson CD, Pickering LK, Sullivan P, DuPont HL. The role of location of food consumption in the prevention of travellers' diarrhoea in Mexico. Gastroenterology 1980;79:812-816

47. KENDRICK MA. Summary of study on illness among Americans visiting Europe, March 31, 1969-March 30, 1970. J Infect Dis 1972;126:685-687.

48. Gangarosa EJ, Kendrick MA, Loewenstein MS, Merson MH, Mosley JW. Harry G. Armstrong lecture: Global travel and travellers' health. Aviat Space Environ Med 1980;51:265-270.

49. FARTHING MJ. Travellers;diarrhoea. Gut 1994;35:1-4.

50. Gonzalez-Cortes A, Gangorosa EJ, Parrilla C, et al. Bottled beverages and typhoid fever: the Mexican epidemic of 1972-73. Am J Public Health 1982;72:844-845.

51. SCOTt DA, Haberberger RL, Thornton SA, Hyams KC. Norfloxacin for the prophylaxis of travellers' diarrhoea in U.S. military personnel. Am J Trop Med Hyg 1990;42:160164.

52. Rademaker CM, Hoepelman IM, Wolfhagen MJ, BEUMER H, Rozenberg-ARSKa M, VERHOEF J. Results of a double-blind placebo-controlled study using ciprofloxacin for prevention of travellers' diarrhoea. Eur J Clin Microbiol Infect Dis 1989;8:690-694.

53. Wistrom J, Norrby SR, Burman LG, Lundholm R, JELLHEDEN B, ENGLUND G. Norfloxacin versus placebo for prophylaxis against travellers' diarrhoea. J Antimicrob Chemother 1987;20:563-574.

54. ERICSSON CD, DuPONT HL, Galindo E, et al. Efficacy of bicozamycin in preventing travellers' diarrhoea. Gastroenterology 1985;88:473-477.

55. ECheVerRia P, SACK RB, BLACKLOw NR, et al. Prophylactic doxycycline for travellers' diarrhoea in Thailand. Further supportive evidence of Aeromonas hydrophila as an enteric pathogen. Am J Epidemiol 1984;120:912-921.

56. DuPont HL, Galindo E, Evans DG, Cabada FJ, Sullivan P, Evans DJ, JR. Prevention of travellers' diarrhoea with trimethoprim-sulfamethoxazole and trimethoprim alone. Gastroenterology 1983;84:75-80.

57. Black FT, GaArslev K, Orskov F, et al. Mecillinam, a 
new prophylactic for travellers' diarrhoea. A prospective double-blind study in tourists travelling to Egypt and the Far East. Scand J Infect Dis 1983;15:189-193.

58. SACK RB. Antimicrobial prophylaxis of travellers' diarrhoea: a summary of studies using doxycycline or trimethoprim and sulphamethoxazole. Scand $J$ Gastroenterol (Suppl) 1983;84:111-117.

59. RICHARDS DA. Prophylactic value of clioquinol against travellers' diarrhoea. Lancet 1971;1:44-45.

60. Anonymous. Travellers' diarrhoea: National Institutes of Health Concensus Development Conference. Bethesda, Maryland, January 28-30, 1985. Rev Infect Dis 1986;8 (Suppl 2):S109-233.

61. DuPont HL, Sullivan P, Evans DG, et al. Prevention of travellers' diarrhoea (emporiatric enteritis). Prophylactic administration of subsalicylate bismuth). JAMA 1980;243:237-241.

62. SMITH HW, Halls S. The experimental infection of calves with bacteriaemia-producing strains of Escherichia coli: the influence of colostrum. $J$ Med Microbiol 1968;1:61-78.

63. SMITH HW, HALLS S. The production of oedema disease and diarrhoea in weaned pigs by the oral administration of Escherichia coli: factors that influence the course of the experimental disease. J Med Microbiol 1968;1:45-59.

64. Porter P. Transfer of immunoglobulins IgG, IgA and IgM to lacteal secretions in the parturient sow and their absorption by the neonatal piglet. Biochim Biophys Acta 1969;181:381-392.

65. Rejnek J, Kostka J, Travnicek J. Studies on the immunoglobulin spectrum of porcine serum and colostrum. Folia Microbiol (Praha) 1966;11:173-178.

66. BAglionI T, FIORETTI C, Serum immunoglobulins in colostrum and cow's milk studied by the immunoelectrophoretic method. Arch Vet Ital 1967;18:419-427.

67. TACKet CO, Losonsky G, Link H, et al. Protection by milk immunoglobulin concentrate against oral challenge with enterotoxigenic Escherichia coli. $N$ Engl J Med 1988;318:1240-1243.

68. Oksanen PJ, Salminen S, Saxelin M, et al. Prevention of travellers' diarrhoea by Lactobacillus GG. Ann Med 1990; 22:53-56.

69. De dios Pozo-Olano J, Warram JH, Jr., Gomez RG, Cavazos MG. Effect of a lactobacilli preparation on travellers' diarrhoea. A randomized, double blind clinical trial. Gastroenterology 1978;74:829-830.

70. Guarino A, Canani RB, Spagnuolo Mi, Albano F, Di BENEDETTO L. Oral bacterial therapy reduces the duration of symptoms and of viral excretion in children with mild diarrhoea. J Pediatr Gastroenterol Nutr 1997;25:516-519.

71. Shornikova AV, Casas ia, Mykkanen H, Salo E, VESIKARI T. Bacteriotherapy with Lactobacillus reuteri in rotavirus gastroenteritis. Pediatr Infect Dis J 1997;16:11031107.

72. PANT AR, GRaham SM, AlLEN SJ, et al. Lactobacillus GG and acute diarrhoea in young children in the tropics. J Trop Pediatr 1996;42:162-165.

73. Majamaa H, Isolauri E, SaXelin M, Vesikari T. Lactic acid bacteria in the treatment of acute rotavirus gastroenteritis. J Pediatr Gastroenterol Nutr 1995;20:333-338.

74. Clemens JD, SACK DA, HaRris JR, et al. Cross-protection by $\mathrm{B}$ subunit-whole cell cholera vaccine against diarrhoea associated with heat-labile toxin-producing enterotoxigenic Escherichia coli: results of a large-scale field trial. $J$ Infect Dis 1988;158:372-377.

75. Peltola H, Sittonen A, Kyronseppa H, et al. Prevention of travellers' diarrhoea by oral B-subunit/whole-cell cholera vaccine. Lancet 1991;338:1285-1289.

76. BANWELL JG. Treatment of travellers' diarrhoea: fluid and dietary management. Rev Infect Dis 1986;8(Suppl 2):S1827.

77. Rautanen T, Kurki S, Vesikari T. Randomised double blind study of hypotonic oral rehydration solution in diarrhoea. Arch Dis Child 1997;76:272-274.

78. FARTHING MJ. Oral rehydration therapy. Pharmocol Ther 1994;64:477-492.

79. Anonymous. Multicentre evaluation of reduced-osmolarity oral rehydration salts solution. International Study Group on Reduced-osmolarity ORS solutions. Lancet 1995;345:282 285.

80. Thillainayagam AV, Hunt JB, Farthing MJ. Enhancing clinical efficacy of oral rehydration therapy: is low osmolality the key? Gastroenterology 1998;114:197-210.

81. WAPNIR RA, TURVILL JL, FARTHING MJG. Addition of soluble fibre to the perfusate inhibits cholera toxin-induced secretion. Gastroenterology 1997;112:A418.

82. Go JT, SIA CG, HARPER RG, WAPNIR RA. Oral rehydration solutions (ORS): enhancement by a soluble fiber. $J$ Am Coll Nutr 1994;13:364-368.

83. Wapnir RA, Wingertzahn MA, Moyse J, Teichberg S Gum arabic promotes rate jejunal sodium and wate absorption from oral rehydration solutions in two models of diarrhoea. Gastroenterology 1997;112:1979-1985.

84. WAPNIR RA. Teichberg S, Go JT, Wingertzahn MA HARPER RG. Oral rehydration solutions: enhanced sodium absorption with gum arabic. J Am Coll Nutr 1996;15:377 382.

85. Haider R, Azad Khan AK, Roy SK, Dewan N, Alan AN, MAHALANABIS D, Management of acute diarrhoea in diabetic patients using oral rehydration solutions contining glucose, rice, or glycine. BMJ 1994;308:624-626.

86. Thillainayagam AV, Dias JA, Salim AF, et al. Glucose polymer in the fluid therapy of acute diarrhoea: studies in a model of rotavirus infection in neonatal rats. Clin Sci (Colch) 1994;86:469-477.

87. ERICSSON CD, DuPONT HL, JohnSON PC. Nonantibiotic therapy for travellers' diarrhoea. [Review] [13 refs]. Rev Infect Dis 1986;8(Suppl 2):S202-6.

88. Anonymous. Travellers' diarrhoea. NIH Concensus Development Conference. JAMA 1985;253:2700-2704.

89. STEFFEN R. Worldwide efficacy of bismuth subsalicylate in the treatment of travellers' diarrhoea. Rev Infect Dis 1990;12(Suppl 1):S80-6.

90. JoHnson PC, ERICSSON CD, DuPONT HL, MORGAN DR BITSURA JA, WOOD LV. Comparison of loperamide with bismuth subsalicylate for the treatment of acute travellers diarrhoea. JAMA 1986;255:757-760.

91. DUPONT HL. Nonfluid therapy and selected chemoprophylaxis of acute diarrhoea. Am J Med 1985;78:81-90.

92. Wistrom J, Jertborn M, Hedstrom SA, et al. Short-term self-treatment of travellers' diarrhoea with norfloxacin: placebo-controlled study. $J$ Antimicrob Chemother 1989;23:905-913.

93. DuPont HL. Ericsson CD, Mathewson JJ, de la Cabada FJ, ConRAD DA. Oral aztreonam, a poorly absorbed yet effective therapy for bacterial diarrhoea in US travellers to Mexico. JAMA 1992;267:1932-1935.

94. TAYlor DN, SANChez JL, CANDLER W, et al. Treatment of travellers' diarrhoea: ciprofloxacin plus loperamide compared with ciprofloxacin alone. A placebo-controlled randomized trial. Ann Intern Med 1991;114:731-734.

95. Petruccelli BP, Murphy GS, SanChEZ JL, et al. Treatmen 
of travellers' diarrhoea with ciprofloxacin and loperamide. $J$ Infect Dis 1992;165:557-560.

96. Murray BE, Mathewson JJ, DuPont HL, Ericsson CD, REVES RR. Emergence of resistant fecal Escherichia coli in travellers not taking prophylactic antimicrobial agents. Antimicrob Agents Chemother 1990;34:515-518.

97. DutTa P, Mitra U, Rasally R, et al. Multi-drug resistant typhoid fever with diarrhoea. Indian Pediatr 1997;34:891899.
98. Wistrom J, Gentry LO, Palmgren AC, et al. Ecological $\complement$ effects of short-term ciprofloxacin treatment of travellers' diarrhoea. J Antimicrob Chemother 1992;30:693-706.

99. Ellis C. Diarrhoea in the returned traveller. Practitioner 1996;240:188-192. 